\title{
NOEMATIC ANALYSIS OF IMAGE CONSCIOUSNESS
}

\section{Carlos Morujão}

Portuguese Catholic University

\section{Image consciousness and imagination}

Image consciousness and imagination are, in common language, very often vague and indefinite concepts. Husserl prefers to use the term Phantasie to refer to what we usually name with the word imagination, and calls its product Phantasievorstellung, that is, the fantasy representation. Image consciousness (Bildbewusstsein) appears every time a physical representation makes possible the intuitive representation of an absent object. But, sometimes, Husserl uses the concepts of «fantasy», «imagination» (Imagination), or even «simple imagination» (slichte Imagination ${ }^{1}$ ) to refer generally to these two distinct situations: on the one hand, image consciousness and, on the other, the creation of fantasy products, like a literary work or a film ${ }^{2}$. In this way, it seems that Husserl's term «fantasy» has both a wide and a strict meaning. There is, nevertheless, a fundamental difference between the sensible contents which these two types of image representation offer: sensations, in the cases of image consciousness, and fantasized images (Phantasmen) in the case of fantasy in the strict sense ${ }^{3}$.

We can look at these differences in another way. By looking at a photograph, I place the perceived object in the set of my perceptive space -

1 Maria Manuela Saraiva, in L'Imagination selon Husserl, La Haye, Martinus Nijhoff, 1970, p. 58, speaks of imagination au sens strict.

2 Husserl, Phantasie, Bildbewusstsein, Erinnerung, in Husserliana Band XXIII (henceforth: Hua, followed by the number of the volume in roman characters), §14, p. 29.

${ }^{3}$ Idem, Ibidem, (Beilage I, $\S 7$ ) pp. 123-124. This is a text from 1898 but that Husserl takes up again in his 1904-05 Lecture about fantasy and image consciousness.

Phainomenon, n. ${ }^{\circ} 25$, Lisboa, pp. 203-214

DOI: 10.2478 /phainomenon-2012-0002

(C) 2012 Morujão. This is an open access article licensed under the Creative Commons AttributionNonCommercial-NoDerivs License (http://creativecommons.org/licenses/by-nc-nd/3.0/). 
the photographic image is hanging on the wall or standing on my desk - while I exclude the photographed object from any connection with it. Cinema's visual space, on the contrary, has the power to substitute real space, creating a cinematographic space with peculiar characteristics. Just like any other product of fantasy consciousness, a cinematographic work shares with other works of the same type the fact that it is the result of a modification of the content of reality we normally attribute to the different layers of meaning which compose our life-world. In Experience and Judgement, Husserl says that to the objectivities of fantasy there corresponds a quasi-positionality ${ }^{4}$, which means they cannot be related to the perceived objectivities in the unity of a common world.

But it's for this reason that cinema's particular case seems easier to analyze than photography, at least if we consider the latter only as portrait or landscape photography. The point is that in the case of photography we need to make three distinctions; that is, we distinguish, first, the material support we can find, for example, in a frame hanging on the wall and that has the same kind of physical nature as any other perceptible object entering the visual field: Husserl calls this support the physische Bild, the physical image; secondly, what is represented in it, a child, for example, if it's the portrait of a child, das abbildende Objekt or, simply, Bildobjekt, the image object (a term which seems to me unfortunate, since I can't understand what there can be in the word «object» that would suit what is here at stake); and, finally, the object it represents das abgebildete Objekt, which in our example will be the child herself that is portrayed there and whom we could say the portrait more or less resembles 5 . (In the Logical Investigations, Husserl uses the expression «image subject», Bildsujet ${ }^{6}$.) The distinction between the image object and the image subject becomes even more apparent - even if it can add some further complicating factors - when we think of a black-and-white portrait of a child or a landscape which, naturally, as flesh and bone child and real landscape have quite different colors. Paradoxically, we are faced with something which does not exist as such in real space-time and which, nevertheless, is visible in an image in the spatial context of a photograph. The color of the abbildende Objekt is not necessarily that of the abgebildetes Objekt. Everything that has been constituted as image can contradict the perceptive experience of the thing it represents, while that is not the case with fantasy.

\footnotetext{
${ }^{4}$ Idem, Erfahrung und Urteil (henceforth: EU), Hamburg, Felix Meiner, 1999, § 39, p. 195.

${ }^{5}$ Idem, Phantasie, Bildbewusstsein, Erinnerung, Hua XXIII, § 9, p. 19.

${ }^{6}$ Idem, Logische Untersuchungen, Zweiter Band, Erster Teil, V (Henceforth: LU V), Hua XIX/1, p. 436.
} 


\section{Image and reality}

Another situation phenomenological analysis calls our attention to is the one which occurs when we interpret a work of art - and here photography and film provide us with privileged examples - in terms of the resemblance which it has, as we usually and imprecisely say, with the reality it is an image of. It's necessary to call attention to the numerous dangers that come from the use of this terminology, since it's usual, both in common language and in some philosophies, to call mental image to that which does not have the character of an image, since it was not constituted as such by an act of consciousness. This happens, for example, when we say we have ideas that are images or mental representations ${ }^{7}$ of things and that our relation to things is done by intermediary of those images, which we place in our minds. This is a rough conception which is not confirmed by any analysis of our mental life but which is, nonetheless, quite common. We only have mental images, in the only legitimate sense of the term (which Husserl also calls spiritual images, geistiger Bilder ${ }^{8}$ ), as a particular variety of image consciousness, when a perceived object evokes, by its similarities, another that is not being perceived at the same time.

Now, Husserl underlines that the image consciousness and fantasy result from a special type of intentional activity that is not present when we notice a resemblance and is, therefore, irreducible to the latter. If I look at a photograph of the Tower of Belém, the abgebildete Objekt is the Tower itself and not something that resembles it; of course I can look at a blurry picture and say: «it looks like the Tower of Belém», but even in this case the abgebildete Objekt cannot be identified with the Abbildung, that is, its configuration process. However, in the case of seeing two pictures of the Tower of Belém, taken from slightly different angles, I could say they are similar pictures. The resemblance, in this case, isn't of the Tower of Belém as a noematic correlate of the image consciousness - since that would be making the absurd statement that the Tower of Belém resembles itself - but rather of the Abbildung.

There is still one other important distinction to consider. An image's material support is not mistaken for the image world. Normally, a thematic look will not focus on that support: Eugen Fink said that its phenomenal mode of presence consists in omission'. It is then possible to put forth the following general thesis: the support of the image world is not the noematic

\footnotetext{
7 Idem, LU V, Hua XIX/1, p. 436.

${ }^{8}$ Idem, Phantasie, Bildbewusstsein, Erinnerung, Hua XXIII, p. 17.

${ }^{9}$ Eugen Fink, «Vergegenwärtigung und Bild», trad. franc. «Re-présentation et image» in De la Phénoménologie, Paris, Éditions du Minuit, 1974, pp. 15-93, p. 89.
} 
correlate of image consciousness. Now, just like in the normal case of image consciousness, in fantasy consciousness what interests us isn't the support of the fantasy world: the roll of cinematographic film, the digital support, the printed paper, etc. (Although an excess of grain on a film, or any other factor of the same kind, can make one's attention focus on the support. Or other possible cases: a film buff or critic can, while watching a film, focus his attention on a poor directing job, for example, the lack of raccord between two shots, or the imperfect lighting. But I'll leave these questions aside.) But in the case of film, the question becomes again more complicated than in photography, at least if we don't consider all the specific problems that come from documentary films. As a fiction work, a film does not count as an image. An image supposes, as I've said above, a support that is connected to other objects belonging to the same space-time continuum. If in his first lessons on this matter and, partly, even still in Logical Investigations, Husserl was not always able to clearly establish the difference between image consciousness and fantasy consciousness; since 1904-05 and, particularly, since Ideas $I$, thanks to the notion of neutralization, the situation becomes completely different.

The phenomenon Husserl calls «neutralization» or «neutrality modification», is the base of fantasy consciousness. In this way, we'll speak of a modification of the ego cogito's intentional activity who, by fantasizing, realizes a constitution in the «as if» mode ${ }^{10}$. Using Husserl's analyses from $\S \S 109$ to 112 of Ideas $I$, in the 1929 essay mentioned in footnote 9, Eugen Fink distinguishes two fundamental kinds of this modification ${ }^{11}$, of which only the second will be of interest to our issue. 1) First, what he calls «realization neutrality». This is a difficult phenomenon to analyze; Husserl says it really was never determined terminologically and that most of the times it was confused with other belief modifications. Fink states it is one of those cases where the ego lives without the intimate weight of its own existence in such a way that the correlates of its acts cannot be affirmed or predicated. (States like mourning and melancholy, in the sense Freud gave to these terms, could perhaps be presented as examples; this, in fact, seems to be in agreement with Husserl's statement in $\S 112$ of Ideas $I$, according to which this type of neutralization cannot be accomplished twice; in this way, I can't, for example, mourn my mourning ${ }^{12}$.) 2) Secondly, we have «content neutrality». Now, the operation is

${ }^{10}$ Idem, Ibidem, p. 84.

${ }^{11}$ Idem. Ibidem, pp. 84-85.

${ }^{12}$ Husserl, Ideen zu einer reinen Phänomenologie und phänomenologischen Philosophie, § 112, Hua III, pp. 270-271. Husserl says: «[...] die Phantasiemodifikation als Vergegenwärti- 
executed over the content of the act itself: that is, we don't make unreal what we had previously put forth as real, since the unreality now belongs to the noema itself.

This neutrality of content means that, faced with a fantasy product, we are more interested in the appearing than in the thing that appears ${ }^{13}$, that is, we are more interested in the quality of the intentional act than in its matter, which can actually be the same in an act of perception or recollection. At the origin of aesthetic interest is a neutralized presentification. Of course not all interest in an appearing is of an aesthetic kind; for the latter to emerge it's necessary it doesn't arise from cognitive order goals such as, for example, those of psychology. In order to situate ourselves in the attitude which corresponds to the aesthetical point of view, there needs to occur a withholding of the belief in the existence of a thing in its worldly character and in all that qualifies it as a worldly object. In this way, Husserl says the aesthetic consciousness is a nichtsetzende Bewusstsein, it's a non-positional consciousness, although, of course, this does not mean all non-positional consciousnesses are aesthetic; when we modify the quality of a certain intentional act - when, for example, the belief in $\mathrm{X}$ is changed into a doubt about the existence of $\mathrm{X}$-, consciousness goes from being positional to non-positional, without there being here any fantasy consciousness ${ }^{14}$. Kant discusses a similar problem in the Critique of Judgment when he asks whether it is possible to speak of the pure beauty of an animal, for example, a horse. Kant's response is negative, insofar as it «adheres» to the figure of the horse a set of representations which direct us to the utility we find in a really existing horse. In phenomenological terms, we could say that the noema «horse» is always qualified by determinations pertaining to the manners in which we constitute it in our life-world experiences; we can't, in the case of a horse, entirely «neutralize» this experience and eliminate all the sendimentations or levels of meaning that have been deposited in it.

Of course I am talking about the beauty of a perceived, or perceivable, horse, that is, a horse that is or can be there, leibhaftig $d a$, in flesh and blood (or, as we can also say, in person) and not of a horse that is merely presentified (vergegenwärtigt), that is, that appears, as Husserl says, im Bild ${ }^{15}$. Im Bild or in an image, a horse appears only «as if» it was there - als wäre es $d a$, says the German expression in the XXIII volume of Husserliana -, it is only presentified without being truly present.

gung iterierbar ist (es gibt Phantasien beliebiger Stufe: Phantasien "in" Phantasien), während die Wiederholung der "Operation" der Neutralisierung wesensmässig ausgeschlossen ist.»

${ }^{13}$ Idem, Phantasie, Bildbewusstsein, Erinnerung, Hua XXIII, p. 145.

${ }^{14}$ Idem, LU V, Hua XIX/1, pp. 507-508.

${ }^{15}$ Idem, Phantasie, Bildbewusstsein, Erinnerung, Hua XXIII, § 8, p. 16. 


\section{Fixing our terminology}

Let's fasten our terminology in order to avoid possible confusions. Husserl distinguishes between Gegenwärtigung and Vergegenwärtigung, presentation and presentification; the first situation occurs when an object can be perceived, the second takes place in the remaining cases. However, both Gegenwärtigung and Vergegenwärtigung have the character of an intuition; a remembered object, for example, is not less intuitively present than a perceived object, it is only differently so. Among the modalities of presentification we can count remembering, expectation, image consciousness and fantasy; knowledge of the alter-ego can also be considered a form of presentification, but it raises such specific issues that this paper is not the right place to try to approach them.

In comparison with other forms of presentification, remembering (Wiedererinnerung) is specific in one regard. With it, I am close to the past, I live in the midst of a past situation, in the world of my old experience. There isn't here an image consciousness. Every image consciousness presentifies, but not all presentifications are image consciousness. Remembering is a type of consciousness which is essentially reproductive, which is incapable of allocating new determinations to its object. That's why we should say that when we are remembering, we are evoking old perceptions. Nevertheless, Wiedererinnerung can highlight in a particular way what was once neglected, that which we did not pay enough attention to ${ }^{16}$.

In products of fantasy there is a world, with its own space and time, that is presentified. In it, there is a flux of present moments, flowing towards the past. But that specific worldly time does not coincide with the temporality of the actual ego and has no relation to the present in which the fantasy's lived experience is constituted ${ }^{17}$; there does seem to be, nonetheless, a characteristic which it shares with our worldly time: its irreversibility ${ }^{18}$.

The fundamental characteristic of the originary constitution of the pre-given world in perception is passivity. It is over a background of passive syntheses, as Husserl says, that the ego's activity takes place. Now, in the case of presentifications - be they recollections, image consciousness or fantasy -, the opposite seems to occur ${ }^{19}$. In these cases, the background seems to be activity: I recollect, I'm in front of an image, or I fantasize, even if, in the

${ }^{16}$ Idem, Ibidem, pp. 43-47.

${ }^{17}$ Idem, Ibidem, pp. 60-61.

${ }^{18}$ Cf. Alfred Schutz, "On multiple realities», in Collected Papers I, The Hague, Martinus Nijhoff, 1982, pp. 207-259, p. 239.

${ }^{19}$ Fink, Ibidem, p. 67. 
course of those presentifications I am so absorbed that my activity seems to have disappeared. Eugen Fink claims that this apparent freedom of the ego constitutes a kind of suspension of care (Sorge), in the sense given to this term by Martin Heidegger in Being and Time ${ }^{20}$. This leads us directly to the problematic of Hitchcock's film, Rear Window. The protagonist in the film is living one of these moments where the Sorge seems suspended, in his case, due to an accident that forbids him from walking and keeps him at home.

Further on, I will mention the particular spatiality of this fantasy world that arrives from the suspension of care. For now, I would like to call attention to an important aspect of Hitchcock's film which characterizes a fantasy world or, in this case, James Stewart's fantasy world, inside that phantasy world that is already for us, spectators, the film Rear Window. In the real world, we often make mistakes: we think we see something that turns out to be something else, or we believe someone to be acting with an intention that he does not have. Husserl calls this type of experiences Täuschungen (illusions), and describes the modalities of their appearing and their rectification, both in Ideas $I$ as well as, in more detail, in Experience and Judgment ${ }^{21}$. But the world that will absorb James Stewart does not include these correcting experiences. It is true that it is a world which has some doubtful aspects, but the doubt is not dispelled via a more careful look at the reality in which things happen. In this way similar to Cervantes' Don Quixote, James Stewart replaces his mistake that is, the deception which is caused by an unrealized expectation - by a new fictional construction that will, supposedly, show him he was actually correct. Of course, his rather peculiar situation - the forced immobility caused by a broken leg - forbids him a better view-point. He can get the world closer to his eyes with the help of his lens, but he can't execute those bodily movements that make natural perception what it really is. He can't move around the objects to see the other side. What Fink calls, as was mentioned earlier, the «as-if» world - an expression that also appears in Husserl, for example in $\$ 74$ of Experience and Judgement - (a world we also fall into when we decide to watch this or any other film) is the world in which, in the film itself, we see James Stewart, his girlfriend and his nurse fall into ${ }^{22}$. It is only that for them - like for Don Quixote in Cervantes' novel - it is not an «as-if» world, but rather a fragment of the real world.

${ }^{20}$ Idem, Ibidem, p. 86.

${ }^{21}$ Husserl, EU, $\S 21$ b, pp. 99 and ff.

${ }^{22}$ Idem, EU, § 74, p. 360. Husserl says: «Von dem Phantasierenden, der in der Phantasiewelt lebt (vom "Träumenden"), können wir nicht sagen, dass er Fikta als Fikta setzt, sondern er hat modifiezierte Wirklichkeiten, Wirklichkeiten-als-ob.» 


\section{The noema in normal perception and in film}

Every act of presentation is a mix of presences and absences. Some parts of the presented objectivity hide other parts, like the surface, for example, hides the interior. In a cinematographic image, that does not happen. Of course I can imagine myself in the situation I see in the film and realize in it all the intentional operations I realize in the real world. It is, in fact, that possibility I normally project unto the situations I see on the screen. But it is also this projection that gives the object seen on the screen a noematic layer that it does not have if it is perceived in the real world ${ }^{23}$ : of what is happening in a film, I can only see what is projected on the screen. For this reason, there is a similarity between cinematographic images and recollections, despite the fact that recollections are not a kind of fantasy consciousness and that the doxic modalities of fantasy consciousness and recollection are completely different: but there is, in both these cases, an absence I cannot overcome, like I would be able to overcome the absence of the other side of the perceived object by moving around it. This particular cinematographic space is not, for me, a kinesthetic space: I can't move through this space to get closer or farther from the objects that fill it, although I can come closer or farther from the screen where the images are projected. I can't touch or be touched by the bodies that live in those cinematographic spaces. There is an «I can» which is inherent to the life of consciousness unfolding in real space, as Husserl insists in Ideas II and in the Cartesian Meditations, that cannot take place in the merely visual space that is cinematographic space ${ }^{24}$.

Certain camera movements have the capacity to give me the ability of this projection of the intentional operations I realize in real space onto cinematographic space. Some elementary rules of film directing like, for example, the raccord, also have an identical purpose: what is the raccord if not, ultimately, the recognition that the various perspectives of the same object should agree, so that the object is always recognized as being the same? The raccord confirms Husserl's central idea according to which the identity of an object is not given in the same way as its sides or perspectives, but rather in a quite different dimension from all of them ${ }^{25}$. But it is important to keep in mind the very important characteristic this situation always has in film. A film is composed of a series of discontinuous units - the frames that hide their discontinuity by the manner in which they are impressed upon

${ }^{23}$ Robert Sokolowski, Introduction to Phenomenology, trans. Introdução à Fenomenologia, São Paulo, Ed. Loyola, 2004, p. 76.

${ }^{24}$ Husserl Cartesianische Meditationen, $\S \S 19$ and 46, Hua I, pp. 82 e 133.

${ }^{25}$ Sokolowski, Ibidem, p. 75. 
the retina. If we looked at each of the frames separately, we will have the presentification of the visual appearance of a given object or group of objects. It is precisely the way in which this multiplicity of frames is ordered in the unity of the film that allows for a set of events to unfold temporally for the spectator $^{26}$. This discontinuity does not exist in normal perception. Of course it's possible to perceive the parts of an object in discontinuous phases, that is, in moments of time separated by longer or shorter intervals; but the flux of the life of consciousness makes each one of those phases intrinsically temporal, since in each one of them we can see there is the retention of the immediately preceding phases - as well as their noematic correlates - and the protention of the following phases, with the expectation associated with it, of intuitive fulfillment by new perspectives or nuances of that same perceived objectivity.

The vision we can have of an object on a screen does not correspond to the perception we have of it in a «normal» situation. I am not now talking about the impossibility of being able to see from different perspectives; the «I can» that characterizes the ego cogito - the possibility of multiplying its intentions over one same thing - is here considerably reduced in its power. My point is: although I can still fantasize freely about how an object would look if it was seen from «another side», the possibility of realizing that fantasy is dependent upon what the camera gives me, that is, its framing.

But there is more. In normal perception I can move closer or farther from the object, or merely dilate or contract the pupil. On the screen, it's the camera's movements that accomplish this operation and they do it in such a way that I get perspectives on the object that no looking would allow. When the film isn't fiction but is, for example, a documentary, or a teaching aid in a classroom, this dimension becomes essential: the film reveals details that the contemplation of the object in normal conditions - with a naked eye - would not be able to capture ${ }^{27}$.

There is something in all the phenomena I have just described that is not sufficiently explained by the Husserlian notion of neutralization. We saw that, on the one hand, the perception we have of a fictional object or state of affairs has to be consistent with the one we have regarding real objects. The congruence of the perspectives of the same object has, in both cases, to be of the same type. Nevertheless, there is a problem here. If I perceive a house in real life, I'll admit there is a back of the building that corresponds to its front that I could possibly see, or that is, at least in principle, visible by somebody.

${ }^{26}$ Roman Ingarden, Das literarische Kunstwerk, trans. A Obra de Arte Literária, Lisboa, Fundação Calouste Gulbenkian, 1965, p. 354.

${ }^{27}$ Idem, Ibidem, p. 358. 
At the cinema, most times I am seeing movie sets. As someone familiar with the film making techniques, I know that the front of a house seen on a movie screen may not have a back; nevertheless, as a spectator living in a fantasy world, I'll suppose just the opposite. There seems to be here something more than a neutralization, a certain modality of intentional life that cannot be described using only that concept.

Maybe there isn't a phenomenological concept that is precise enough to designate that relation between the multiplicity of frames and its unity which, concretely, constitutes every cinematographic film; each frame could be thought as the part of a whole, but the two modality types of relation between the parts and the whole that Husserl distinguishes in the 3rd Logical Investigation do not seem to apply here. The frame can either be seen as an independent part of the whole (what Husserl calls ein Stück) since I am able to think of it without the whole (and eventually even tear it apart from it, without even making the spectator aware of its absence), or as a dependent part of it (what Husserl calls ein Moment), since without that whole it becomes a simple photographic image ${ }^{28}$.

There are also some important differences between imagination or fantasy consciousness and other forms of presentification when it comes to the noetic perspective. In fantasy consciousness there is a suspension of our usual beliefs ${ }^{29}$, but the world surrounding the fantasizing subject isn't penetrated by the feeling of unreality. It goes on existing, as do the walls of the movie theater, the chair we are sitting on, or the other spectators. What seems particular to film - we can't find it in photography nor, at least with the same degree of intensity, in television - is the fact that it creates a visual space capable of substituting our perceptive space.

$* * * * * * * * * * *$

What makes Hitchcock's film particularly interesting is the fact that the protagonist, the actor James Stewart, is facing the space he can contemplate from the rear window of his apartment in a situation very similar to that of a film spectator facing cinematographic space. His situation of forced immobility reinforces that impression. The space he contemplates, the back of a building that faces the back of his, and the small segment of street he can observe between the distance that separates this building from the other,

${ }^{28}$ Husserl, Logische Untersuchungen, Zweiter Band, Erster Teil, III, §§ 2-3, Hua XIX/1, pp. 231-234.

29 Sokolowski, Ibidem, pp. 80-81. 
is not a kinesthetic space. James Stewart can't come closer or farther, can't move around it to see what is hiding behind it, and it's this situation that increases his capacity to fantasize. Curiously, none of the other film characters seem to be able to free themselves from the same condition of spectators, although they could be more than that, that is, although they would able to establish a normal relation with their world. The abnormality of the film's protagonist becomes contagious; there is even a kind of perverse enjoyment of that condition, and Hitchcock's maliciousness is in making us understand that the same enjoyment can be contagious also for us, spectators.

\section{Bibliography}

FINK, Eugen «Vergegenwärtigung und Bild», trad. franc., «Re-présentation et image» in De la Phénoménologie, Paris, Éditions du Minuit, 1974, pp. 15-93.

Hussert, Edmund, Cartesianische Meditationen, Husserliana Band I, Den Haag, Martinus Nijhoff, 1950.

------- Ideen zu einer reinen Phänomenologie und phänomenologischen Philosophie, Husserliana Band III, Den Haag, Martinus Nijhoff, 1950.

--.-Phantasie, Bildbewusstsein, Erinnerung, Husserliana Band XXIII, Den Haag / Boston / Lancaster, Kluwer Academic Press, 1980.

- Logische Untersuchungen, Zweiter Band, Erster Teil, Husserliana XIX/1, Den Haag, Martinus Nijhoff, 1984.

---Erfahrung und Urteil, Hamburg, Felix Meiner, 1999.

InGARDEn, Roman, Das literarische Kunstwerk, trad. port., A Obra de Arte Literária, Lisboa, Fundação Calouste Gulbenkian, 1965.

SaraIva, Maria Manuela, L'Imagination selon Husserl, La Haye, Martinus Nijhoff, 1970.

Schutz, Alfred, «On multiple realities», in Collected Papers I, The Hague, Martinus Nijhoff, 1982, pp. 207-259.

Sokolowski, Robert, Introduction to Phenomenology, trad. brasileira, Introdução à Fenomenologia, São Paulo, Ed. Loyola, 2004.

\section{ABSTRACT}

This paper addresses Husserl's theory of image consciousness and phantasy, which, along with remembering, constitute three kinds of presentification, a sort of intuitive intentional relational different from perception. In the second place, the paper tries to highlight the significance of «neutralization» - as a means to access the world of phantasy - for the understanding of the origin of the aesthetic attitude. Finally, the paper discusses the kind of spacial relations that arise from «neutralization», in contrast with life-world experience of space, and how those relations can be exemplified in Alfred Hitchcock's The Rear Window. 
Carlos Morujão is Associate Professor with Tenure at the Portuguese Catholic University, and Director of the R\&D Unit Center of Philosophical Studies. His main area of interest in Husserl's phenomenology, about which he has lectured and written extensively in the last years. 